\title{
A Flipped Instructional Design as an Online Pedagogy Enabling Student Learning in an ODeL Course
}

\author{
Micheal M. van Wyk, University of South Africa, Pretoria, South Africa
}

iD https://orcid.org/0000-0001-5536-1362

\begin{abstract}
The growing body of literature is reporting positive results when it comes to flipped learning, which across disciplines and contexts involves student-centered, technology-integrated teaching. Capitalized this paper seeks to examine the impact of the flipped instructional design (FID) as an online pedagogy on students' learning. This paper employed a pragmatic approach, an explanatory mixed-methods design. This paper concluded that the flipped instructional design does engage student learning and empowers them in terms of modeling to teach during the course. Undeniably, this scholarly endeavor revealed that benefits outweighed drawbacks regarding the functionality, usefulness, personalized learning outcomes, freeing up time, collaboration, and active participation towards self-directed learning. The flipped instructional design strategy was used as reliable, relevant, and appropriate to search scholarly works systematically, but more research needs to be conducted for an ODeL environment.
\end{abstract}

\section{KEYWORDS}

Explanatory Mixed Methods, Flipped Instructional Design, Open Distance E-Learning, Reflective Journal, Systematic Scoping Review, Teaching Methodology

\section{INTRODUCTION}

The Education 4.0 era represents a "tipping point" of rapid growth as a paradigm shift, providing an accelerated launching of onine learning for higher education characterized by ventures into blended, distributed and open distance e-learning (ODeL) (World Economic Forum, 2015; 2016; Rojewski \& Hill, 2017; Yusuf \& Nur, 2019). This requires according to Makridakis (2017) that academics need to respond to the "exponential power" of Education 4.0 technologies (Hussin, 2018; Fick, 2017). For consistency, the term "flipped learning" is used throughout this paper. The growing body of literature is reporting positive results when it comes to flipped learning" which across disciplines and contexts involves student-centered, technology-integrated teaching. Empirically, flipped classroom pedagogy of flip learning reports positive evidence in contact teaching (Shyr \& Chen, 2018; Bergmann \& Sams, 2014; Arnold-Garza, 2014). Followed by blended distance learning environments (Gloudeman, ShahManek, Wong, \& Ip, 2018; Stöhr, Demazière, \& Adawi, 2020) - and, to a lesser extent, the distance education context (Graf, Kinshuk \& Liu, 2009; Yusuf \& Nur, 2019). The Education 4.0 technologies 
exponentially continue to grow rapidly in open distance e-learning spaces (Fick, 2017; van Wyk, 2018). At these open distance e-learning spaces, new technologies and applications are being developed to support students' personalized learning (López Belmonte, Guerrero, Sánchez 2020; World Economic Forum, 2017). In support of the latter challenging notions of online pedagogy, in particular, the processes involved in "flipped" learning, and how students learn in an open distance e-learning environment necessitated this inquiry. To successfully, embrace the Education 4.0 paradigm in a socially sustainable way lecturers will need to transform their praxis and rethink the implementation of existing curricula. The researcher opines that it is imperative to capacitate student teachers with digital literacy competencies, digital e-tools, and Education 4.0 technologies for the Education 4.0. Collectively, these empirical evidence presented important insights into the flipped classroom peadagy. This paper seeks to examine the impact of the development of a flipped instructional design (FID) as an online pedagogy on students' learning. To achieve this purpose, the research questions are:

- How do students experience the flipped instructional design as an online pedagogy on students' learning in an ODeL teacher education course?

- To what extent does the flipped instructional design enables students in modeling to teach the Teaching Methodology of Economics course?

- How do Postgraduate Certificate of Education (PGCE) vs Batchelor of Education (Bed) studentteachers views statistically significantly different in the use of the FID as an ODeL supportive strategy?

- How do students encounter non-responsive support and accessibility challenges when using the flipped instructional design?

\section{Background}

Education 4.0 seeks to respond to changes in the knowledge economy by using technologies and innovative pedagogies exponentially as way to continue to grow rapidly in teacher education. In the quest to support student learning, it is reported that ubiquitous disruptive pedagogies and supported students learning becoming more innovative. It is imperative to reimagine alternative pedagogies to improve student learning for ODeL learning environment. To successfully, embrace the Education 4.0 paradigm in a socially sustainable way, in particular, the author will need to transform the praxis and rethink the implementation of existing curricula. The implications are that it is imperative to empower student teachers with digital literacy competencies, digital e-tools, and Education 4.0 technologies at ODeL college for teacher education. In the quest to create learning space to motivate, support, improve academic performance and self-directed learning for students, the author came across Etienne and Beverly Wenger-Trayner's (2014) chapter on a social space of exercising as a collective as a social activity. The chapter challenges the author's view of social learning. This "thought-provoking" text of highly acclaimed scholars gave the author immense pleasure to venture into innovative pedagogies, like flipped learning. It prompted an intended decision to the researcher's "sell-by-date pedagogy", towards "innovative-in-the-moment-pedagogies" to be accommodated of an inclusive student population in an ODeL space. Another "turning-point" was the gazetted "lock-downs" by governments to protect citizens over the spread of COVID-19 pandemic globally. Governments were forced to close businesses, schools, and universities. Many hours of teaching and learning, in particular contact residential universities were lost which impacted on throughput-rates. To "catch-up" for lost time, universities started with online teaching initiatives. Universities started to reimage pedagogical strategies to support students. On the other hand, open universities and distance education service providers were much geared and prepared as compared to contact universities. Distance education and open learning universities were less affected as compared to contact universities. These two tippingpoint shifts have been increased online teaching. Universities were compelled a critical reflection and 
reimaging of exploring with innovative approaches, in particular, flipped learning to support student learning in an ODeL teacher education course.

\section{LITERATURE REVIEW}

The theories that foreground this paper, namely the connectivity theory (Siemens, 2005), and selfdirected learning theory (Knowles, 1975) and online learning community (Griswold et al. 2004; Cope \& Kalantzis 2009) are briefly explained for the study. The connectivity theory is used in a connected ODeL space. Students are regulating their learning as independent and responsible learners by taking pride in their learning efforts (Knowles, 1975). Paris and Paris (2001) agreed with Knowles (1975) that students employ different processes for learning to regulate or to adjust their learning experiences to achieve planned learning goals. In this study, the lecturer serves as an e-mentor and e-tutor to support students in the course when the students solve problems in real situations. According to Griswold et al. (2004), as well as Cope and Kalantzis (2009), the online learning community is used as a situated collaborative and cooperative learning online support. Furthermore, student learning is seen as an autonomous process that contributes to personal gains (Bergman \& Sams, 2014; Stöhr et al., 2020). These claims about self-directed learning are the basis for the argument that student teachers initiate and transform their learning utilizing the flipped class pedagogical strategy. This strategy encourages student teachers to exercise self-control and use purpose-driven and goal-orientated means to enhance self-regulation.

The search for relevant articles for this review found that extensive research was published on flipped learning in different subjects, across disciplines and contexts. Flipped learning impacts and promotes student-centered learning achievement, positively (Zainuddin et al., 2019). Flipped learning teaching strategy impacts students' learning outcomes (Low \& Hew, 2017), increases students' higher-order thinking skills (Blau \& Shamir-Inbal, 2017) and promotes peer-to-peer interactions, academically (Kurt, 2017). Furthermore, flipped learning course methods in higher education seem to increase digital literacy levels and application of students' learning experiences (Sun, Xie \& Anderman, 2018). Moreover, it enhances interaction and engagement among students and teachers in learning through application and practice (van Wyk, 2018). Flipped learning supports self-efficacy, personal and optimal learning opportunities, inclusive of all students (Sams \& Bergman, 2013; Hodges \& Dubinski-Weber, 2015). Finally, studies show that flipped learning positively motivates students' intrinsic motivation and enhances critical thinking and problem-solving skills (Zainuddin et al., 2019; Ozudogru, \& Aksu, 2020;).

In the various studies reviewed, questions were raised, such as whether students in an online space will buy into flipped classroom approaches. Some studies report that students do not prepare well for the in-class time and those with struggling students who cannot keep up with the pace and can easily become discouraged in the learning process. In an online environment, lecturers carefully need to plan assignments, take-home examinations and tasks. Furthermore, studies also reported that no assurance can be given that flipped learning will work in every context. Studies showed that lecturers view flipped learning as a disruptive pedagogical strategy creating doubt, and distrust on the part of learners/students (Fulton, 2012). Also, a study by Ertmer, Otterbein-Leftwich, Sendurur, and Sendurur (2012) reported that lecturers showed a negative attitude and unwillingness to change to student-centered pedagogies. Finally, Inan and Lowther (2010) reported that lack of in-service training in ICT integration and ongoing ICT support as direct factors influencing teachers' unwillingness to adopt and integrate ICT in the classroom.

\section{Context of the Flipped Instructional Design for a Teaching an ODeL Course}

In the ODeL course, learning is accessible and open to all students, locally and internationally. Lecturers and students are connecting for online engaging at anytime, everywhere, anyplace as a means to advancing learinng. The ODeL flipped instructional design as a teaching approach is used 


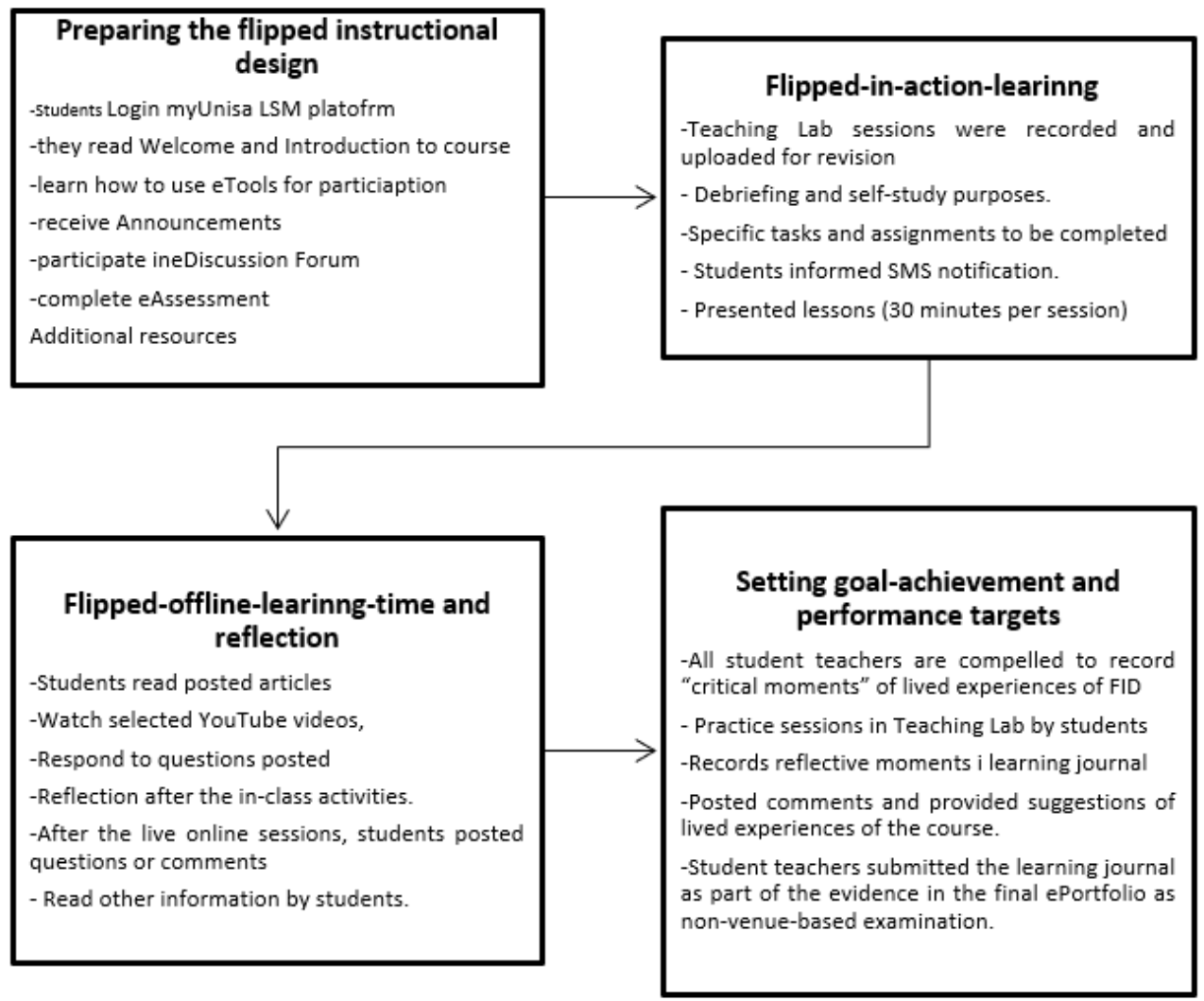

widely at Unisa through the myUnisa LMS platform offering access for applications, learning, studentcenteredness, and support to all students. Students participate in online activities, communicate with lecturers, other students via discussion forums, blogs, and announcements. For this study, the flipped instructional design was purposively designed for the online year course, Teaching Methodology of Economics (TMS3709). About this paper, an online-situated learning platform, myUnisa, is used for students' participation and engagement. Van Wyk (2018) argues that students must be empowered to practice a variety of learner centredness teaching approaches, in particular, the flipped instructional design, to become competent future teachers. To implement the FID, four steps (figure 1), namely, (i) preparation of the flipped instructional design, (ii) flipped-in-action-learning, (iii) flipped-offlinelearning-time for reflection and (iv) setting goal-achievement and performance targets in the process for implementing the flipped instructional design.

\section{METHODOLOGY}

In preparation for conducting the research, and the ethical application was submitted and approved by the College Ethics Committee (Certificate Ref \#2018 RPSC_017). The College Ethics Policy Guidelines stipulated the requirements of applying ethical principles in conducting research. At all-time ethics must be applied professionally. Registered research projects approved within the College must adhere to the principles, standards, regulations, confidentiality and ethical practices. The researcher acted ethically in a professional manner during the data collection and fieldwork. All participants 
were respected for their views, believes, opinions and values expressed. It was clearly stated to all registered sampled students in the course that no student will be penalized for the non-completion of the FIDQ questionnaire. Students were ensured of their right to withdraw at any time.

This case study, mixed methods design, was prepared according to procedure used by Creswell (2012) and Bakla (2018). An online closed-structured questionnaire, called the flipped instructional design (FIDQ) was sent to 204 students with an online link to be completed, anonymously. The convenient and purposive sampled students in the Teaching Methodology of Economics course, comprised of 117 PGCE and 87 Bed (Senior and Further Education and Training phase) were selected. The questionnaire was designed from an extensive scoping review on flipped learning. The exploratory quantitative data was presented in the form of cross-tabulations, one-way ANOVA, exploratory factor analysis, Mann-Whitney U test and Wilcox W for significance between PGCE vs Bed students. A reliability test was computed for the self-designed questionnaire for the FIDQ instrument $(\alpha<0.887)$. An exploratory factor analysis (EFA) was computed as a scientific way to determining the studentteachers views of the flipped learning of underlying patterns amongst variables.

The qualitative data included learning journal entries. Student recordings of "critical moments" of lived experiences in the reflective learning journal. These student reflections on experiences posted comments and provided suggestions of lived experiences of the course. The data analysis process was employed for the Learning Journal entries, as advocated by Creswell (2012) content analysis approach. All learning journal entries were downloaded from myUnisa. Themes were identified manually according to topics posted for the learning journal of the effect of the flipped instructional design. Twenty percent (62 of 311) of learning journal entries were used for the qualitative part of this paper. The reason being, data sets were validated and ensured the trustworthiness according to procedure as stipluated by Creswell (2012). This process ensured the credibility displayed extracts from the interviewees as true reflection.

\section{RESULTS}

\section{Quantitative Results}

\section{PGCE vs Bed Students' Experiences Wthin the Flipped Instructional Design}

Results revealed that ninety-four percent (94\%) of student teachers $\left(M=3.98 ; S D=1.871 ; p<1.627^{* *}\right.$; $\left.\mathrm{p}<.000^{*}\right)$ agreed significantly that modeling through the FID strategy supports them to learn to teach in the Teaching Methodology of Economics. Besides, students were positively influenced by the strategy that placed them at the center of learning by this strategy. The lecturer for the Teaching Methodology of Economics course prepared and uploaded self-created videos of flipped learning as work-integrated-practice exemplars. These self-designed videos supporting students to practice and modeling in becoming competent teachers. The lecturer recorded videos for students modelled or to practice with the intention to guide them what to expect once they complete the course ( $M=$ 3.94; $\left.\mathrm{SD}=1.871 ; \mathrm{p}<1.523^{* *} ; \mathrm{p}<.000^{*}\right)$. This is another significant finding of the positive impact of the flipped learning strategy. These two findings are very important outcomes of what student teachers expected from the course. Student teachers agreed $(\mathrm{p}<.05)$ that the flipped learning strategy promoted modeling in the subject significantly $(\mathrm{p}<.001)$.

\section{The Role of the Lecturer in Supporting Students' Modeling in Flipped Instructional Design}

Results have shown that eighty-nine percent (89\%) of respondents supported $(\mathrm{M}=3.91 ; \mathrm{SD}=1.398$; $\left.\mathrm{p}<1.717^{* *} ; \mathrm{p}<.000^{*}\right)$ that the lecturer in modeling a role in an FID teaching strategy created opportunities for them to learn the subject. Furthermore, they positively viewed the role the lecturer plays in planning, designing and creating learning material for in-class and out-of-class times which 
Table 1. Paired differences between PGCE vs Bed students' experiences of modeling in FID

\begin{tabular}{|c|c|c|c|c|c|c|}
\hline \multirow[t]{2}{*}{ Statements on the modeling of the FID } & \multicolumn{3}{|c|}{ Paired Differences } & \multicolumn{3}{|c|}{ Sampled t-test for significance } \\
\hline & $M$ & $S D$ & $\begin{array}{c}S E \\
\text { Mean }\end{array}$ & $t$ & $d f$ & $\begin{array}{c}\text { Sig. } \\
(2-\text { tailred })\end{array}$ \\
\hline $\begin{array}{l}\text { It models opportunities for me to participate } \\
\text { actively in learning to teach the subject }\end{array}$ & 3.51 & 1.670 & 0.165 & $1.507 * *$ & 71 & $.000 *$ \\
\hline $\begin{array}{l}\text { It models by involving me in planning } \\
\text { lessons for practice of learning materials in } \\
\text { the course }\end{array}$ & 3.09 & 1.334 & 0.105 & $1.097 * *$ & 71 & $.003^{*}$ \\
\hline $\begin{array}{l}\text { It promotes students' learning process to } \\
\text { reflect on personalized learning }\end{array}$ & 3.98 & 1.871 & 0.115 & $1.627 * *$ & 71 & $.000 *$ \\
\hline $\begin{array}{l}\text { It models me for what to expect as a future } \\
\text { teacher by making informed decisions as a } \\
\text { responsible learner }\end{array}$ & 3.94 & 1.781 & 0.135 & $1.523 * *$ & 71 & $.000 *$ \\
\hline $\begin{array}{l}\text { It models my pace of learning throughout } \\
\text { the course by becoming actively involved in } \\
\text { learning to teach }\end{array}$ & 3.51 & 1.799 & 0.115 & $1.317^{* *}$ & 71 & $.002 *$ \\
\hline $\begin{array}{l}\text { It gives me a realistic view of what to expect } \\
\text { in reality (in practice) }\end{array}$ & 3.64 & 1.401 & 0.165 & $1.287 * *$ & 71 & $.001^{*}$ \\
\hline $\begin{array}{l}\text { It enables me to cooperate, engage and } \\
\text { collaborate with other students as an online } \\
\text { strategy }\end{array}$ & 3.79 & 1.641 & 0.265 & $1.507 * *$ & 71 & $.000 *$ \\
\hline $\begin{array}{l}\text { It provides me with digital literacy skills to } \\
\text { negotiate an online learning environment } \\
\text { and participate during in-class time }\end{array}$ & 2.38 & 1.321 & 0.161 & $1.322 * *$ & 71 & $.000 *$ \\
\hline $\begin{array}{l}\text { It models me to learn to teach by freeing } \\
\text { up my time and practice what I have been } \\
\text { learned in the course }\end{array}$ & 2.89 & 1.556 & 0.215 & $1.455^{* *}$ & 71 & $.000 *$ \\
\hline $\begin{array}{l}\text { It creates opportunities for experimental } \\
\text { learning by studying modeling videos and } \\
\text { other learning materials }\end{array}$ & 3. 11 & 1.651 & 0.205 & $1.211^{* *}$ & 71 & $.000 *$ \\
\hline $\begin{array}{l}\text { It supports me to keep track of my learning } \\
\text { experiences by posted information in my } \\
\text { learning journal }\end{array}$ & 3.63 & 1.464 & 0.123 & $1.207 * *$ & 71 & $.000 *$ \\
\hline
\end{tabular}

${ }^{*} p<.05,2$-tailed ${ }^{* *} p<.001$

they can use to become efficient in teaching $\left(\mathrm{M}=3.72 ; \mathrm{SD}=1.251 ; \mathrm{p}<1.507^{* *} ; \mathrm{p}<.000^{*}\right)$. This result demonstrated a significant finding of the positive impact of the flipped learning strategy

\section{Statistical Analysis, a One-Way Analysis of Variances (ANOVA), was Calculated Student Teachers' Views of Flipped Learning (see Table 3).}

The one-way ANOVA revealed that the F-ratios between-group mean squares were statistically significant. However, there may be a variance amongst the scores of sampled students, statistically. To find out, a rigor commonly used tests, the Mann-Whitney U-value (PGCE vs Bed students) and Wilcox W (related FID strategy and online course) were computed.

The significance level is for both groups $(\mathrm{p}=0.014$ i.e. $\mathrm{p}<0.05)$. This implies that both groups are statistically significantly different. In sum, the Mann-Whitney U test does not enable the researcher to identify clearly where the differences lie between PGCE vs Bed students. 
Table 2. Students views of the lecturer's role in the FID

\begin{tabular}{|l|l|l|l|l|l|l|}
\hline \multicolumn{1}{|c|}{$\begin{array}{c}\text { Statements related to the role of lecturer in } \\
\text { modeling the role in the FID }\end{array}$} & \multicolumn{3}{c|}{ Paired Differences } & \multicolumn{2}{c|}{ Sampled t-test for significance } \\
\cline { 2 - 7 } & $M$ & $S D$ & $\begin{array}{c}\text { Se } \\
\text { Mean }\end{array}$ & & \multicolumn{1}{c|}{$\begin{array}{c}\text { Sig. } \\
\text { (2-tailred) }\end{array}$} \\
\hline $\begin{array}{l}\text { Lecturer planned learning material for in-class } \\
\text { and out-of-class times }\end{array}$ & 3.87 & 1.509 & 0.165 & $1.507^{* *}$ & 69 & $.000^{*}$ \\
\hline $\begin{array}{l}\text { The lecturer decides what to be covered in each } \\
\text { learning task for the in-class and out-of-class time }\end{array}$ & 3.66 & 1.414 & 0.105 & $1.097^{* *}$ & 69 & $.005^{*}$ \\
\hline $\begin{array}{l}\text { The lecturer gives clear instructions for what } \\
\text { needs to be done for homework and during live } \\
\text { online teaching sessionsi as per learning goals }\end{array}$ & 3.61 & 1.451 & 0.115 & $1.627^{* *}$ & 69 & $.000^{*}$ \\
\hline $\begin{array}{l}\text { The lecturer provides constructive feedback on } \\
\text { completed out-of-class tasks }\end{array}$ & 2.09 & 1.018 & 0.135 & $1.523^{* *}$ & 69 & $.000^{*}$ \\
\hline $\begin{array}{l}\text { The lecturer models lessons for students to watch } \\
\text { to provide teaching practice }\end{array}$ & 3.91 & 1.398 & 0.115 & $1.717^{* *}$ & 69 & $.000^{*}$ \\
\hline $\begin{array}{l}\text { The lecturer models lessons for students to be } \\
\text { studied and used for reflection on learning to } \\
\text { teach. }\end{array}$ & 3.72 & 1.251 & 0.165 & $1.507^{* *}$ & 69 & $.000^{*}$ \\
\hline $\begin{array}{l}\text { The lecturer carefully selects learning material to } \\
\text { be studied for in-class and out-of-class times with } \\
\text { the purpose of self-paced learning }\end{array}$ & 3.67 & 1.451 & 0.105 & $1.097^{* *}$ & 69 & $.005^{*}$ \\
\hline $\begin{array}{l}\text { The lecturer provided clear guidelines regarding } \\
\text { what information to be recorded in the learning } \\
\text { journal }\end{array}$ & 3.18 & 1.131 & 0.115 & $1.627^{* *}$ & 69 & $.000^{*}$ \\
\hline
\end{tabular}

${ }^{*} p<.05,2$-tailed ${ }^{* *} p<.001$

Table 3. One-way ANOVA computed student teachers views of FID

\begin{tabular}{|l|c|c|c|c|c|c|}
\hline \multirow{2}{*}{ Statements of responses to the FID strategy } & $\begin{array}{c}\text { Sum of } \\
\text { squares }\end{array}$ & Df & M square & F & Sig. \\
\hline $\begin{array}{l}\text { Modeling learning in } \\
\text { the teaching strategy }\end{array}$ & Between Groups & 1.728 & 2 & 2641.049 & 7.110 & $0.000^{*}$ \\
\cline { 2 - 7 } & Within Groups & 9.639 & 26 & 371.451 & & \\
\cline { 2 - 7 } & Total & $\mathbf{1 1 . 3 6 7}$ & $\mathbf{2 8}$ & & & \\
\hline $\begin{array}{l}\text { The modeling role of the } \\
\text { teacher in the strategy }\end{array}$ & Between Groups & 2.798 & 2 & 1229.399 & 4.833 & $0.000^{*}$ \\
\cline { 2 - 7 } & Within Groups & 9.243 & 26 & 254.356 & & \\
\cline { 2 - 7 } & Total & $\mathbf{1 2 . 0 4 1}$ & $\mathbf{2 8}$ & & & \\
\hline $\begin{array}{l}\text { Students'views of } \\
\text { gains in supporting } \\
\text { self-paced learning }\end{array}$ & Between Groups & .462 & 2 & 2509.231 & 8.297 & $0.000^{*}$ \\
\cline { 2 - 7 } & Within Groups & 10.629 & 26 & 302.409 & & \\
\hline
\end{tabular}

$p<0.001$

\section{Students Experiences of the Flipped Instructional Design in Modeling the ODeL Course}

Eighty-nine percent $(89 \%)$ of the respondents agreed $(\mathrm{M}=3.61 ; \mathrm{SD}=1.356)$ that the FID as a supportive strategy promoted active student involvement in learning. Furthermore, students agreed 
Table 4. Students experiences of FID as a supportive strategy in the course $(n=204)$

\begin{tabular}{|c|c|c|c|c|c|c|}
\hline $\begin{array}{l}\text { Statements related to the FID strategy } \\
\text { supporting self-paced learning }\end{array}$ & M & SD & $\begin{array}{l}\text { Strongly } \\
\text { Agree }\end{array}$ & Agree & Disagree & $\begin{array}{l}\text { Strongly } \\
\text { Disagree }\end{array}$ \\
\hline $\begin{array}{l}\text { FID is a supportive strategy promotes an } \\
\text { engaged, active, supportive and enhancing } \\
\text { space for students' learning }\end{array}$ & 3.61 & 1.356 & $89 \%$ & $11 \%$ & - & - \\
\hline $\begin{array}{l}\text { FID is a supportive strategy provides ample } \\
\text { time, whether to engage with other students, } \\
\text { applying of and reflectiing on learning } \\
\text { content towards self-directed learning }\end{array}$ & 3.67 & 1.722 & $87 \%$ & $10 \%$ & $3 \%$ & - \\
\hline $\begin{array}{l}\text { FID is a supportive strategy promotes an } \\
\text { interactive learning space conducive for } \\
\text { problem-based learning, peer collaborative } \\
\text { strategies and activities to achieve learning } \\
\text { objectives in the course }\end{array}$ & 3.00 & 1.433 & $40 \%$ & $54 \%$ & $6 \%$ & - \\
\hline $\begin{array}{l}\text { FID ia a supportive strategy that is } \\
\text { effective, in modeling which is vital for the } \\
\text { design of learning activities for optimal } \\
\text { learning towards students' thinking }\end{array}$ & 3.36 & 1.651 & $43 \%$ & $54 \%$ & $3 \%$ & - \\
\hline $\begin{array}{l}\text { FID is a supportive strategy that gives } \\
\text { students a realistic view of what to expect } \\
\text { in reality when they become professional } \\
\text { teachers }\end{array}$ & 3.44 & 1.465 & $80 \%$ & $11 \%$ & $9 \%$ & - \\
\hline $\begin{array}{l}\text { FID is a supportive strategy that provides } \\
\text { me with digital literacy skills, knowledge } \\
\text { and values on how to be effective in an } \\
\text { online learning environment }\end{array}$ & 3.41 & 1.438 & $40 \%$ & $60 \%$ & - & - \\
\hline $\begin{array}{l}\text { FID is a supportive strategy that frees } \\
\text { up time and provides support to students } \\
\text { learning to teach }\end{array}$ & 3.06 & 1.023 & $7 \%$ & $71 \%$ & $22 \%$ & - \\
\hline $\begin{array}{l}\text { FID is a supportive strategy that supports } \\
\text { students in self-paced learning and } \\
\text { becoming actively involved in learning to } \\
\text { teach the subject }\end{array}$ & 3.09 & 1.191 & $10 \%$ & $83 \%$ & $7 \%$ & - \\
\hline $\begin{array}{l}\text { FID is a supportive strategy that provides } \\
\text { students an opportunity to reflect by } \\
\text { experimenting in the learning process of } \\
\text { becoming future teachers }\end{array}$ & 2.77 & 1.471 & $33 \%$ & $60 \%$ & $7 \%$ & - \\
\hline
\end{tabular}

$(87 \%)$ that the strategy provided ample time, whether the FID is a supportive strategy provides ample time, whether to engage with other students, applying of and reflectiing on learning content towards self-directed learning $(\mathrm{M}=3.67 ; \mathrm{SD}=1.722)$. Overall, student teachers were positive about FID supporting self-paced learning.

\section{Factors Extracted From Student Teachers' Responses on the Use of the FID.}

The purpose of extracting factors from the data set, a rotated components matrix in the principal component analysis (PCA) were computed. An exploratory factor analysis (EFA) determining the student-teachers views related to the flipped learning of underlying patterns amongst of variables.

The PCA computed five extracted exploratory factors (F1, F2, F3, F4 and F5). All the extracted factors are statistically significant $(\alpha<0.7)$. It is evident that respondents were different in their onlin learning because they experienced the ODeL flipped learning experience, positively. Female students 
Table 5. Extracted factors from student teachers' responses to the FID $(n=204)$

\begin{tabular}{|l|l|l|l|l|l|}
\hline & \multicolumn{1}{|c|}{ Factorised items emerging from data analysis } & \multicolumn{1}{|c|}{$\begin{array}{c}\text { Mean } \\
\text { Male }\end{array}$} & \multicolumn{1}{|c|}{$\begin{array}{c}\text { Mean } \\
\text { Female }\end{array}$} & \multicolumn{1}{|c|}{ t-test } & $\boldsymbol{\alpha}=\mathbf{0 . 7}$ \\
\hline F1 & $\begin{array}{l}\text { Flipped the class as a student-centered learning } \\
\text { strategy for modeling to learn to teach }\end{array}$ & 3.59 & 3.77 & $0.000^{* *}$ & $0.782^{*}$ \\
\hline F2 & $\begin{array}{l}\text { The usefulness of flipped the class to achieve } \\
\text { success in the course }\end{array}$ & 3.22 & 3.15 & $0.000^{* *}$ & $0.823^{*}$ \\
\hline F3 & $\begin{array}{l}\text { Creating learning opportunities for experimental } \\
\text { learning }\end{array}$ & 3.24 & 3.53 & $0.000^{* *}$ & $0.881^{*}$ \\
\hline F4 & $\begin{array}{l}\text { Enhancing freed-up time, increasing interaction and } \\
\text { collaboration amongst students }\end{array}$ & 3.26 & 3.57 & $0.000^{* *}$ & $0.849^{*}$ \\
\hline F5 & $\begin{array}{l}\text { Reflection on my learning journey throughout the } \\
\text { course }\end{array}$ & 3.62 & 3.38 & $0.000^{* *}$ & $0.791^{*}$ \\
\hline
\end{tabular}

${ }^{* *} p<0.001 ;{ }^{*} a=0.7$

view the use of the FID strategy $\left(\mathrm{F} 1=3.77 ; 0.000^{* *} ; \mathrm{F} 3=3.53 ; 0.000^{* *} ; \mathrm{F} 4=3.57 ; 0.000^{* *}\right)$ significantly as compared to male students. Male students view the usefulness of flipped the class to achieve success in the course $\left(\mathrm{F} 2=3.22 ; 0.000^{* *}\right)$ and reflection on my learning journey throughout the course ( $\mathrm{F} 5=3.62 ; 0.000 * *)$. Results indicated that student teachers viewed the use of the flipped learning strategy, significantly $(0.002 * *$ to $0.000 * *)$.

\section{Comparison for the Registered Group (PGCE vs Bed) on the Extracted Factors (Table 6).}

In Table 6 a t-test was computed to determine the relationship between PGCE vs Bed related to the strategy $p<0.000 ; p<0.002$. It is observed (see Table 6) that the BEd group had higher scores than the PGCE group in terms of modeling as a strategy to learn to teach in the course.

\section{Qualitative Results}

The researcher downloaded the Learning Journal entries send by emails. According to procedure as stipluated by Creswell (2012), themes were manually identify and aligned to extracts posted in the Learning journals. Three themes emerged from the interview process, explicitly,

(i) Creating an engaged modeling space for learning using a flipped instructional design for empowering students with pedagogical skills to practice in becoming a competent student-teacher;

Table 6. Group statistics of PGCE vs Bed students on the modeling of the FID teaching strategy

\begin{tabular}{|l|l|l|l|l|l|l|}
\hline \multirow{2}{*}{$\begin{array}{c}\text { EFA computed to extract factors from FIDQ- } \\
\text { items }\end{array}$} & \multicolumn{2}{|c|}{ PGCE (n=117) } & \multicolumn{2}{|c|}{ BEd (n=87) } & \multicolumn{2}{c|}{ Stats. Significance } \\
\cline { 2 - 7 } & M & SD & M & SD & t-test & \multicolumn{1}{|c|}{ p=.7 } \\
\hline $\begin{array}{l}\text { Students learn to teach in modeling in the } \\
\text { practice of using the FCP teaching strategy }\end{array}$ & 3.679 & 0.578 & 3.711 & 0.905 & $0.001^{* *}$ & $0.882^{*}$ \\
\hline $\begin{array}{l}\text { Lecturer's modeling role in a Flipped Classroom } \\
\text { Pedagogy }\end{array}$ & 3.456 & 0.525 & 3.847 & 0.824 & $0.000^{* *}$ & $0.833^{*}$ \\
\hline $\begin{array}{l}\text { Students' views of the Flipped Class Pedagogy } \\
\text { supporting self-paced learning during the course }\end{array}$ & 3.283 & 0.480 & 3.071 & 0.361 & $0.002^{* *}$ & $0.796^{*}$ \\
\hline
\end{tabular}

${ }^{* *} p<0.001 ;{ }^{*} a=0.7$ 
(ii) Preparing student teachers on the role of the teacher as an online space-creator, e-mentor, e-tutor and e-facilitator in creating effective learning opportunities using a flipped learning strategy;

(iii) Challenges encountered related to non-responsive learning support, labor strikes and nonaccessibility of LMS platform impacting on the use the flipped instructional design

(i) Creating an engaged modeling space for learning using a flipped instructional design for empowering students with pedagogical skills to practice in becoming competent student teachers

Before the course begins, the lecturer planned by creating an interactive space amongst students for active participation. The functionality of the flipped instructional design provided ample opportunity during online or offline class discussions for students to engage in the course. This student alluded to the functionality of the flipped instructional design:

I love the online activities but there was a time that we lost the link. The in-class discussion session was well planned. The online teaching session was something new and I will give it a try in my class someday. For me, this was a good course. I learned a lot about this method (Bed student).

Furthermore, students engage in the application of and reflection on learning content towards self-directed learning. Several students participated, and evidence was echoed by these students:

It was a requirement to get involved in two of our online activities (Blogs and Discussion forum as in the TUT letter 101). I appreciated the engagement with other students during our Teaching Lab-live teaching by prof on cooperative learning (PGCE student).

Given the positive postings of student teachers in the learning journals, the author agreed about the strengths of the flipped instructional design. During the course, the flipped instructional design support interactive learning. The lecturer designed problem-based learning and peer collaborative strategies and activities to achieve learning objectives. The sampled extracted Learning journal entries of the student revealed the FID strategy impacting her studies, positively:

What can I say, I received good support throughout this module? I like active learning strategies. These strategies were explained in online classes and the study guide, so it was easy to follow especially on our project on problem-based learning (PGCE-student).

The study guide, the article, and YouTube videos were supportive, helpful and it guides me and the group what was expected for our group project (PGCE-student)

The most positive outcomes posted in the journals were, namely, students' reflections on lessons learned throughout the course. These students echoed the following sentiments from his learning journal:

Ilearned valuable lessons during the course by recorded my experiences in a journal (PGCE student). Another statement: This module prepares me for what to expect after completion of the course (BEd student)

(ii) Preparing student teachers on the role of the teacher as an online space-creator, e-mentor, e-tutor and e-facilitator in creating effective learning opportunities using a flipped learning strategy 
In an online space, the lecturer became a mentor, e-tutor and facilitator. An online facilitator creates support for slow learners and mindfully enhancing student learning. This female Bed-students wrote in her learning journal:

We learned in one of our other modules about facilitation but in this teaching didactics module, the professor showed us one of his self-made videos on how to facilitate success in the subject. You learned how to accommodate and assist the weak learners. Support learners is a very important aspect of facilitation (BEd student)

As posited earlier about the role the lecturer played in the flipped instructional design, the focus shifted to the position of a designer of learning activities for optimal learning towards students' thinking. This positive entry highlighted the student's view as extracted from the learning journal:

I was impressed on the quality and clarity information provided through the tutorial letters, study guide and extra resources, in particular, the appropriateness of the online YouTube video on Flipped Classroom Pedagogy (PGCE student)

Moreover, students viewed the role the lecturer played in the flipped instructional design as e-instructor or visible onle teacher to enhance student learning. It was indicated in the course tutorial letter. The purpose of using learning journals and topics to be learned out-of-class time. Students wrote in their learning journals:

I like the topics and YouTube videos to be covered and watched for in-class and out-of-class sessions. Clear directions on what and how-to study were most helpful. Thanks a lot for all the support (BEd students)

(iii) Challenges encountered related to on-responsive support, labor strikes, and non-accessibility to LMS platform impacting on the use of the flipped instructional design

In most online cases, the above challenges of non-responsiveness, labor strikes, and nonaccessibility to the LMS platform, emerged and therefore those challenges must be addressed to support students. Online support strategies must be developed by the lecturer such as discussion forums, blogs, booking of telephonic calls, and emails. Non-responsive efforts of students during discussion forums, online teaching sessions were highlighted by several students. This is a big concern when one operates in an online distance education course. This student expressed concern of note (learning journal):

In my group, some of the other students never participated or send their comments to us. I struggled, we completed our project, but I am not happy that only some are working, and others received the same marks. It is unfair to us who work very hard. (PGCE student)

It was a requirement for the Teaching Methodology course that PGCE and Bed- students captured in their learning journals positive observations and challenges of the flipped instructional design. For this purpose, only ten percent of the extracted learning journal entries were used in this paper. After the data analysis process, the following issues emerged from the learning journal entries, namely, inefficient learning materials, non-supportive efforts, student protest, and labor strikes influenced student learning during the course. These were serious issues that must be addressed by the lecturer 
or senior management of the university. These students recorded in the learning journals the following drawbacks:

Some of the YouTube video links were not active and I struggled to connect. I received my study materials very late. myUnisa is sometimes unavailable for participate in forums. (BEd students).

Furthermore, students indicated an overload of information and non-participation in online discussion forums emerged during the course. The following issues were posted:

I was placed in a rural school to do my TP. It was frustrated because of the poor internet connection. Some of my group members do not contribute to our project. I started late to participate in the online e-Discussion forums. (3 BEd students).

The issues of poor quality of YouTube videos and non-existence of internet links are nonaccessible were posted in learning journal entries. This student captured his frustrations and dissatisfaction with the course:

I was frustrated and struggled to access the links provided in the Tutorial letter. When open the links, some YouTube videos were not fit what I expected to do. Poor quality and frustrations. (PGCE student)

\section{DISCUSSION OF FINDINGS}

This paper reported that the flipped instructional design (FID) in the Teaching Methodology of Economics class succeeded in modeling, supporting and actively engaging student teachers in the strategy for personal gains. Empirically, flipped instructional design positively influenced the Teaching Methodology of Economics students' perceptions of the benefits of the FID as a supportive strategy for an online context. Furthermore, student teachers perceived flipped instructional design in the learn to teach experience as engaging, promoting it as useful and effective for their learning. This helps them to reflect throughout their learning journey as a lived experience process.

Firstly, the flipped instructional design promotes an engaging, active and self-paced learning approach that positively supported them throughout their learning journey. This was mentioned by the BEd student in her journal: "I like the flipped learning strategy. These strategies were explained in online classes and the study guide, so it was easy to follow especially on our project on problem-based learning" (female student). Therefore, results showed that ninety-four percent ( $M=3.98 ; \mathrm{SD}=1.871$ ) strongly agree that FID is an appropriate teaching strategy that can be implemented successfully. Scholars report in studies conducted in flipped instructional design, that the strategy engages, models and promote learning whether in contact, blended or distributed learning contexts (Steed, 2012; Sams \& Bergmann, 2013; Stöhr et al., 2020; Keengwe et al., 2014). Similarly, scholars claim that this approach encourages students to be responsible learners and to achieve learning goals (Steed, 2012). A male PGCE student posted in his journal entry that he "appreciated the engagement with other students during our Teaching Lab-live teaching by prof on the topics unemployment, poverty and inflation using the cooperative learning method". Moreover, studies also report that students' increased technology-enhanced flipped learning promotes their self-regulation (Rojewski \& Hill, 2017; Shyr \& Chen 2018) and enhances personal performances and goals (Roehl, Reddy \& Shannon, 2013) when exposed to this strategy. Given this claim, it is also found that the strategy inspires and promotes a sense of responsibility on the side of the student. Furthermore, student teachers strongly agree (94\%) that this digital pedagogical strategy helps them to practice by modeling support to learn to teach in the course. Paris and Paris (2001), agreed with Knowles (1997) that students employ different processes for learning to regulate or to adjust their learning experiences to achieve planned learning 
goals. As stated in this learning journal entry by a PGCE student, "The online teaching session was something new and I will give it a try in my class during my teaching placements". This positive outcome prepares them what to expect of the profession. Secondly, lecturer in the course supports the success of the FID strategy is vital and modeling this strategy for student teachers to engage in learning opportunities guarantees effective learning to teach. Furthermore, Rojewski and Hill (2017), concur that to ensure an optimal learning environment for an ODeL context, the teacher should give clear instructions about what needs to be done for specific activities as per learning goals. Student teachers agreed (89\%) that the lecturer's role in modeling in the FID as a teaching model is crucial for practice teaching in the subject. Students believe that to be effective in the FID strategy, more modeling and practicing of the subject is vital to gain confidence. In doing so, the teacher is compelled to create specific learning opportunities for students to grow as subject specialists. This positive post by a BEd student reveals that he was "impressed on the quality and clarity information provided through the tutorial letters, study guide and extra resources, in particular, the appropriateness of the online YouTube video". To execute this role, the teaching plans, designs and learning material for in-class and out-of-class times should be such that they can model it to become efficient in the teaching of the subject. According to Fulton (2012), the success of this strategy is the role the teacher plays in the planning and modeling of it. Wang and Huang (2018) agree that if this research, wants to obtain success with this FID strategy, as with many other teaching strategies, the lecturer must play a vital instructional part in planning tasks for students to grow in becoming teachers. Thirdly, it was found that FID does support student teachers in modeling to teach in the course (89\%). Abdullah, Alayyar, Almsaud and Almutairi (2019) reported that the strategy better prepared them in the course work by increasing performance. Scholars are of the view that this strategy supported students in promoting a sense of accountability for their learning (Bergmann \& Sams, 2014; Rojewski \& Hill, 2017). According to Shyr and Chen (2018), every student in the course is asked to be responsible and take ownership of the learning process to be successful. But, Kong (2014), view the success of flipped learning is the type of support provided by the teacher in a functional online space for enhancing students' learning capacity and problem-solving skills. Results in this study, statistically showed that student teachers view the support provided by the teacher in the online environment $\left(\mathrm{p}<0.000^{* *}\right)$. Fourthly, students viewed the reflections recorded in the learning journal of lessons learned throughout the course was valuable in the preparation of becoming future teachers. Finally, student teachers were positive of the flipped instructional design as a supporting self-paced learning approach enhancing personalized learning. Given the strengths of the FID strategy, drawbacks emerged such as non-responsiveness, low participation in the Teaching Lab sessions, frequent unavailability of myUnisa, low quality of some self-made videos, labor strikes, and student that influenced student learning. For example, some students raised complaints to rectify or replace those multimedia materials. This extract captured the dissatisfaction of self-made videos, namely "Some of the YouTube videos links were not active and I struggled to connect” (male PGCE student).

\section{THIS STUDY WAS LIMITED TO THE FOLLOWING}

Admittedly, only a small cohort of students' perceptions, reactions, and feelings about flipped instructional design employed in the course. Exclusion of students from other courses in the teacher education program. It is noted that this research was conducted in one course in the teacher education program, which makes it a bit impossible to project the findings onto larger populations.

\section{THE FINDINGS IMPLICATED FURTHER INVESTIGATIONS}

This study extends our knowledge of the flipped instructional design applied in an ODeL course. The evidence from this case study suggests that the flipped instructional design showed positive outcomes which can be applied in future teacher education courses. This research had confirmed 
the findings of Zainuddin, et al. (2019) which found that FID strategy motivates students to learn, promotes online engagement and social interaction. The FIDQ was scientifically proven as a reliable and valid instrument for future investigations. Furthermore, the validation of FIDQ makes a noteworthy contribution to methodologically. A longitudinal study with a larger sample should be undertaken. It would be interesting to access in-service teachers' and prospective students' experiences in designing technology-enhanced learning facilitating students' learning in other teacher education courses. Finally, further investigations warranted exploring students' behavioral patterns in flipped learning in an ODeL space.

\section{CONCLUSION}

This paper concluded that the flipped instructional design does engage students' learning and empowers them in terms of modeling to teach during the course. The flipped instructional design as a teaching strategy was used as reliable, relevant and appropriate to search scholarly works systematically but more research needs to be conducted for an ODeL environment. Specific criteria, such as framing the similarities, differences and "gaps" on flipped instructional design as a teaching strategy, were employed. In executing the scoping review process, specific steps were followed searching for scholarly texts for inclusion in the final review. Given supportive scholarly texts, flipped the economics class does engage, support and promote social interaction amongst student teachers actively in modeling to learn in an ODeL course. To conclude, flipped instructional design was an engaged, active and selfpaced learning approach that enhances students' experiences throughout the ODeL learning journey. For the student teachers, the lecturer plays a vital role in planning, designing and modeling quality learning materials with which they can engage personally. The FIDQ was a reliable scientifically proven instrument, which could be used for future inquiries. It can be replicated in any context which will yield reliable and valid results. Undeniably, this scholarly endeavor revealed that benefits outweighed drawbacks regarding functionality, usefulness, personalized learning outcomes, freeingup-time, collaboration, active participation towards self-directed learning, in particular advancing success, of using this strategy in an ODeL context.

\section{Declaration}

The author declares that there is no competing interest because this manuscript is part of a funded research project entitled, ePortfolio as an alternative assessment strategy in an open distance university.

\section{Availability of Data and Materials}

All materials and raw data sets generated from the research project must be safely stored during and after completion of the project as stipulated by the University of Management Protocol for Ethics and Intellectual Property rights. All data sets, tools, and materials will be subjected to quality assurance purposes as stipulated in the Unisa Data Management Plan and the funder, the National Research Foundation (NRF) for Grant funding (Grant ID \# 113615). 


\section{REFERENCES}

Almodaires, A. A., Alayyar, G. M., Almsaud, T. O., \& Almutairi, F. M. (2019). The Effectiveness of Flipped Learning: A Quasi-Experimental Study of the Perceptions of Kuwaiti Pre-Service Teachers. International Education Studies, 12(1), 10-23. doi:10.5539/ies.v12n1p10

Arnold-Garza, S. (2014). The Flipped Classroom Teaching Model and Its Use For Information Literacy Instruction. Communications in Information Literacy, 8(10), 7-22. doi:10.15760/comminfolit.2014.8.1.161

Bakla, A. (2018). Learner-generated materials in a flipped pronunciation class: A sequential explanatory mixedmethods study. Computers \& Education, 125, 14-38. doi:10.1016/j.compedu.2018.05.017

Bergmann, J., \& Sams, A. (2014). Flipped learning: Gateway to Student Engagement. Learning and Leading with Technology, 41(7), 18-23. https://pdfs.semanticscholar.org/568c/f703d44c70f69de85931dc4e43d05ad37707.pdf

Blau, I., \& Shamir-Inbal, T. (2017). Re-designed flipped learning model in an academic course: The role of cocreation and co-regulation. Computers \& Education, 115, 69-81. doi:10.1016/j.compedu.2017.07.014

Cope, B., \& Kalantzis, M. (2009). Ubiquitous Learning: An Agenda for Educational Transformation. Ubiquitous Learning: An International, 3-14. https://www.lancaster.ac.uk/fss/organisations/netlc/past/nlc2008/abstracts/ PDFs/Cope_576-582.pdf

Creswell, J. W. (2012). Educational Research Planning, Conducting and Evaluating Qualitative and quantitative research ( $4^{\text {th }}$ ed.). Pearson Education.

Ertmer, P. A., Ottenbreit-Leftwich, A. T., Olgun, S., Sendurur, E., \& Sendurur, P. (2012). Teacher Beliefs and Technology Integration Practices: A Critical Relationship. Computers \& Education, 59(2), 423-435. doi:10.1016/j.compedu.2012.02.001

Fick, P. (2017). Education 4.0 ... the future of learning will be dramatically different, in school and throughout life. Retrieved from https://www.thegeniusworks.com/2017/01/future-education-young-everyone-taught-together

Fulton, K. (2012). Upside down and inside out: Flipped Your Classroom to Improve Student Learning. Learning and Leading with Technology, 39(8), 12-17. https://files.eric.ed.gov/fulltext/EJ982840.pdf

Gerstein, J. (2011). The Flipped Classroom Model: A Full Picture. https://usergeneratededucation.wordpress. com/2011/06/13/the-flippedped-classroommodel-a-full-picture

Gloudeman, M. W., Shah-Manek, B., Wong, T. H., Vo, C., \& Ip, E. J. (2018). Use of Condensed Videos in a Flipped Classroom for Pharmaceutical calculations: Student perceptions and Academic performance. Currents in Pharmacy Teaching \& Learning, 10(2), 206-210. doi:10.1016/j.cptl.2017.10.001 PMID:29706277

Graf, S., Yang, G., \& Liu, T. (2009). Automatic, Global and Dynamic Student Modeling in an Ubiquitous Learning Environment. Knowledge Management \& E-Learning: An International Journal, 1(1), 18-35. https:// www.jstor.org/stable/10.2307/jeductechsoci.12.4.3

Griswold, W. G., Shanahan, P., Brown, S. W., Boyer, R., Ratto, M., Shapiro, R. B., \& Truong, T. M. (2004). ActiveCampus: Experiments in Community-oriented Ubiquitous Computing. Computer, 37(10), 73-81. doi:10.1109/MC.2004.149

Hodges, T. S., \& Dubinski-Weber, N. (2015). Making Heads or Tails of Classroom Flipping. Kappa Delta Pi Record, 51(2), 57-63. doi:10.1080/00228958.2015.1023135

Hussin, A. A. (2018). Education 4.0 Made Simple: Ideas for Teaching. International Journal of Education and Literacy Studies, 6(3), 92-98. doi:10.7575/aiac.ijels.v.6n.3p.92

Inan, F. A., \& Lowther, D. L. (2010). Factors Affecting Technology Integration in K-12 Classrooms: A Path Model. Educational Technology Research and Development, 58(2), 137-154. doi:10.1007/s11423-009-9132-y

Keengwe, J., Onchwari, G., \& Oigara, J. (Eds.). (2014). Promoting active learning through the flipped classroom model. Hershey, PA: IGI Global.

Knowles, M. S. (Ed.). (1975). Self-Directed Learning. Follet. 
Kurt, G. (2017). Implementing the Flipped Classroom in Teacher Education: Evidence from Turkey. Educational Technology \& Society, 20(1), 211-221. www.jstor/stable/jedutechsoci.20.1.211

Lin, C.-J., \& Hwang, G.-J. (2018). A Learning Analytics Approach to Investigating Factors Affecting EFL Students' Oral Performance in a Flipped Classroom. Journal of Educational Technology \& Society, 21(2), 205-219. www.jstor.org/stable/26388398

Lo, C. K., \& Hew, K. F. (2017). Using "First Principles of Instruction" to Design Secondary School Mathematics Flipped Classroom: The Findings of Two Exploratory Studies. Educational Technology \& Society, 20(1), 222-236. www.jstor.org/stable/pdf/jedutechsoci.20.1.222.pdf

López Núñez, J. A., López Belmonte, J., Moreno Guerrero, A. J., \& Pozo Sánchez, S. (2020). Effectiveness of Innovate Educational Practices with Flipped Learning and Remote Sensing in Earth and Environmental Sciences-An Exploratory Case Study. Remote Sensing, 12(5), 897. doi:10.3390/rs12050897

Makridakis, S. (2017). The Forthcoming Artificial Intelligence (AI) Revolution: Its Impact on Society and Firms. Futures, 90(1), 46-60. doi:10.1016/j.futures.2017.03.006

Ozudogru, M., \& Aksu, M. (2020). Pre-service teachers' achievement and perceptions of the classroom environment in flipped learning and traditional instruction classes. Australasian Journal of Educational Technology, 27-43. doi:10.14742/ajet.5115

Paris, S. G., \& Paris, A. H. (2001). Classroom Applications of Research on Self-Regulated Learning. Educational Psychologist, 36(2), 89-101. doi:10.1207/S15326985EP3602_4

Penprase, B. E. (2018). The Fourth Industrial Revolution and Higher Education. In N. W. Gleason (Ed.), Higher Education in the Era of the Fourth Industrial Revolution (pp. 207-229). Palgrave Macmillan. doi:10.1007/978981-13-0194-0_9

Phillips, C. R., \& Trainor, J. E. (2014). Millennial Students and the Flipped Classroom. Journal of Business and Educational Leadership, 5(1), 102-112. http://asbbs.org/files/ASBBS2014/PDF/P/Phillips_Trainor(P519-530). pdf

Roehl, A., Linga Reddy, S., \& Shannon, G. J. (2013). The Flipped Classroom: An Opportunity to Engage Millennial Students through Active Learning Strategies. Journal of Family and Consumer Sciences, 105(2), 44-49. doi:10.14307/JFCS105.2.12

Rojewski, J. W., \& Hill, R. B. (2017). A Framework for 21st-Century Career-Technical and Workforce Education Curricula. Peabody Journal of Education, 92(2), 180-191. doi:10.1080/0161956X.2017.1302211

Sams, A., \& Bergmann, J. (2013). Flipped your Students' Learning. Educational Leadership, 70(6), 16-20. http:// www.ascd.org/publications/educational-leadership/mar13/vol70/num06/Flipped-Your-Students'-Learning.aspx

Schwab, K. (2016). The Fourth Industrial Revolution: What It Ms, How to Respond. https://www.weforum.org/ agenda/2016/01/the-fourth-industrialrevolution-what-it-Ms-and-how-to-respond/

Shyr, W., \& Chen, C. (2018). Designing a Technology-enhanced Flipped Learning System to Facilitate Students' Self-regulation and Performance. Journal of Computer Assisted Learning, 34(1), 53-62. doi:10.1111/jcal.12213

Siemens, G. (2005). Connectivism: A Learning Theory for the Digital Age. International Journal of Instructional Technology \& Distance Learning. http://www.itdl.org/Journal/Jan_05/article01.htm

Stayer, J. F. (2012). How Learning in an Inverted Classroom Influences Cooperation, Innovation and Task Orientation? Learning Environments Research, 15(1), 171-193. doi:10.1007/s10984-012-9108-4

Steed, A. (2012). The Flipped Classroom. Teaching Business \& Economics, 16(3), 9-11. https://search.proquest. $\mathrm{com} /$ docview/1315741486?pq-origsite $=$ gscholar

Stöhr, C., Demazière, C., \& Adawi, T. (2020). The polarizing effect of the online flipped classroom. Computers \& Education, 147, 103789. doi:10.1016/j.compedu.2019.103789

Strauss, A., \& Corbin, J. (1994). Grounded Theory Methodology: An Overview. In N. K. Denzin \& Y. S. Lincoln (Eds.), Handbook of Qualitative Research (pp. 1-18). SAGE Publications. 
Sun, Z., Xie, K., \& Anderman, L. H. (2018). The role of self-regulated learning in students' success in flipped undergraduate math courses. The Internet and Higher Education, 36(1), 41-53. doi:10.1016/j.iheduc.2017.09.003

Tucker, B. (2012). The Flipped Classroom. Education Next, 12(1), 82-83. https://www.educationnext.org/files/ ednext_20121_BTucker.pdf

Van Wyk, M.M. (2018). Economics student teachers' views on the usefulness of a flipped classroom pedagogical approach for an open distance eLearning environment. The International Journal of Information and Learning Technology, 35(4), 255-265. 10.1108/IJILT-07-2017-0068

Van Wyk, M. M. (2019). Pedagogical strategies to support economics students' learning at an open distance learning university. Journal of Education, 76(1), 23-46. doi:10.17159/2520-9868/i76a02

Wang, J., Lv, Y., \& Huang, C. (2018). An Investigation on Teaching Performances of Model-based Flipped Classroom for Physics Supported by Modern Teaching Technologies. Computers in Human Behavior, 84, 36-48. doi:10.1016/j.chb.2018.02.018

Wenger-Trayner, E., \& Wenger-Trayner, B. (2014). Learning in landscapes of practice: a framework. In E. WengerTrayner, M. Fenton-O'Creevy, S. Hutchinson, C. Kubiak, \& B. Wenger-Trayner (Eds.), Learning in Landscapes of Practice: Boundaries, Identity, and Knowledgeability (pp. 13-30). Routledge. doi:10.4324/9781315777122-3

World Economic Forum. (2015). Deep Shift - Technology Tipping Points and Societal Impacts. Geneva: World Economic Forum. http://www3.weforum.org/docs/WEF_Future_of_Jobs.pdf

World Economic Forum. (2016). Future of Jobs: Employment, Skills and Workforce Strategy for the Fourth Industrial Revolution. Geneva: World Economic Forum. http://www3.weforum.org/docs/WEF_Future_of_Jobs. pdf

World Economic Forum. (2017). Realizing Human Potential in the Fourth Industrial Revolution - An Agenda for Leaders to Shape the Future of Education, Gender and Work. Presented at World Economic Forum, Geneva. http://www3.weforum.org/docs/WEF_Future_of_Jobs.pdf

Yusuf, B., \& Hamid Busthami, N. A. (2019). Pedagogical Orientation in the Fourth Industrial Revolution: Flipped Classroom Model. In A. Raman \& M. Rathakrishnan (Eds.), Redesigning Higher Education Initiatives for Industry 4.0 (pp. 85-104). IGI Global.

Zainuddin, Z., Huran, H., Li, X., Zhan, Y., \& Chu, S. K. (2019). A systematic review of flipped classroom empirical evidence from different fields: What are the gaps and future trends? On the Horizon, 12(2), 1-15. doi:10.1108/OTH-09-2018-0027 